\title{
The breeding avifauna of Cosmoledo Atoll (Seychelles) with special reference to seabirds: conservation status and international importance
}

\author{
GÉRARD ROCAMORA, CHRIS J. FEARE, ADRIAN SKERRETT, MAJELLA \\ ATHANASE and EDWINA GREIG
}

\begin{abstract}
Summary
Cosmoledo Atoll, in the Aldabra Group, western Indian Ocean, has rarely been visited by scientists. This paper reports the first visit by ornithologists during the south-east monsoon when many seabirds breed. The breeding populations of three species of booby (Sula spp.) and of Sooty Tern Sterna fuscata were censused and all other species of bird seen were recorded. The atoll proved to have globally significant populations of Masked Booby Sula dactylatra of the subspecies melanops, Red-footed Booby S. sula of the subspecies rubripes, and Sooty Tern of the subspecies nubilosa. Cosmoledo also supports populations of landbirds that have forms endemic to the Aldabra group, but whose taxonomy requires examination using molecular techniques. The atoll, although currently uninhabited, suffers the impacts of exotic fauna and flora, including cats and rats, introduced by previous inhabitants. The isolation of Cosmoledo confers some protection, but its value as a centre of biodiversity, and designation as an Important Bird Area by BirdLife International, indicate that formal protection is needed. Political mechanisms for this are suggested, the implementation of which would help to procure funding to enable practical conservation of the atoll's biota.
\end{abstract}

\section{Introduction}

Cosmoledo Atoll ( $9^{\circ} 41^{\prime} \mathrm{S}, 47^{\circ} 35^{\prime} \mathrm{E}$ ) is the second largest atoll of the Aldabra group, a system of raised coral islands situated at the south-western extremity of the Seychelles archipelago. Cosmoledo lies $120 \mathrm{~km}$ east of Aldabra Atoll, 400 $\mathrm{km}$ north-west of Madagascar, $700 \mathrm{~km}$ east of Africa and 1,00o km from Mahé, Seychelles, from where Cosmoledo is administered. The atoll comprises 19 islands with a total land area of 460 ha, surrounding a roughly circular lagoon of 14,500 ha. The three largest islands are Menai (c. 230 ha), Grand Ile (160 ha) and Ile du Sud-Ouest (35 ha) (Figure 1). Five other islands (Grand Polyte, Ile du Nord, Ile Nord-Est, Pagode and Goëlettes) exceed 5 ha and retain significant ornithological interest. Much of the land consists of irregular elevated coral, rising to 2-4 $\mathrm{m}$ above sea level, or sand dunes of up to $17 \mathrm{~m}$ (Grand Ile). The shallow lagoon dries out extensively at low tide, exposing large areas of reef-flats (Bayne et al. 1970).

The geological history of the atoll is poorly known. Like Aldabra, it probably 


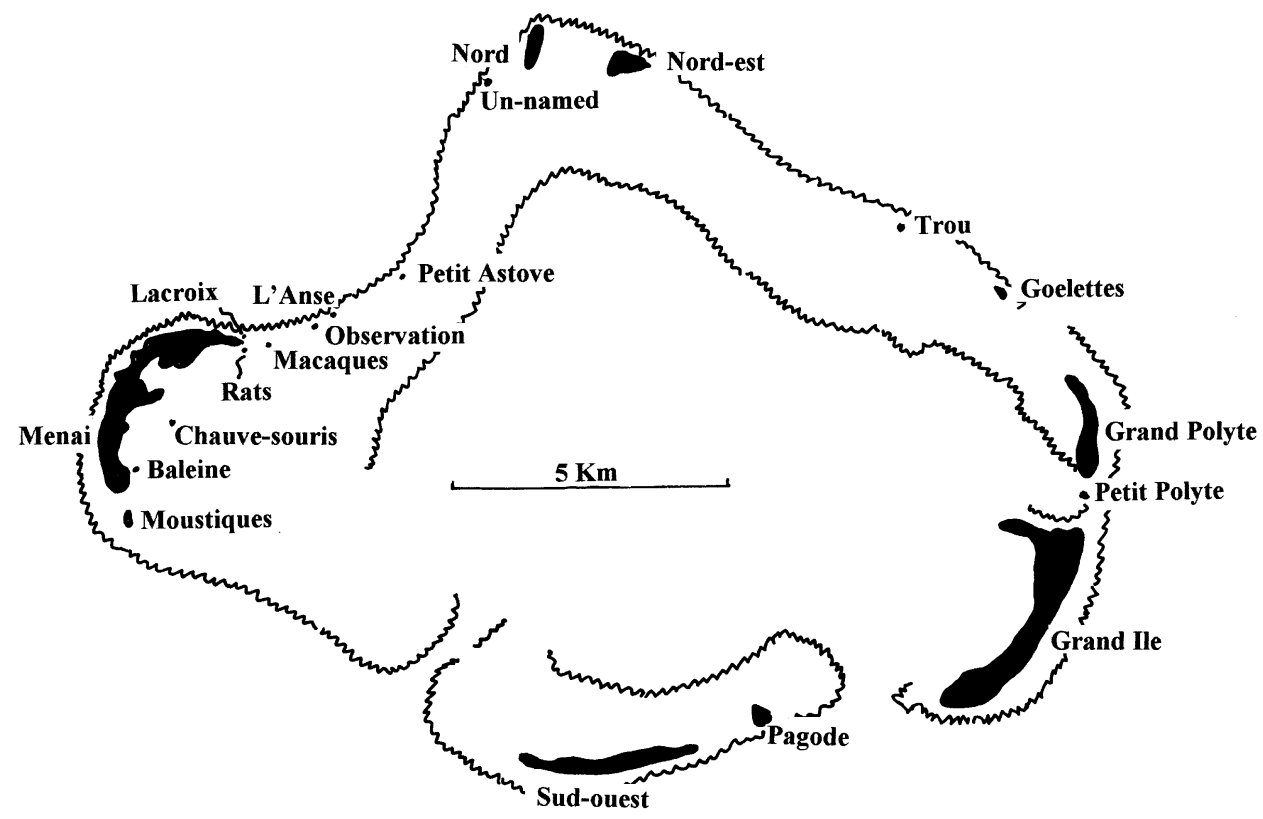

Figure 1. Map of Cosmoledo Atoll with the names of the islands mentioned in the text and tables.

lies on a volcanic (basaltic) foundation c. $1 \mathrm{~km}$ below the surface (Williams 1971) and the limestone may be around 125,000 years old, corresponding with the last interglacial. On the larger islands of Cosmoledo the coral limestone is covered to varying extents by wind-blown sand, sometimes admixed with guano (Piggott 1969), and extensive dune systems are apparent on some.

This remote atoll has rarely been visited by ornithologists and no precise estimates have been produced for the large seabird populations. However some published reports based on short visits between 1878 and 1997 (detailed in Bayne et al. 1970 and Mortimer and Constance 2000) have been made. These visits highlighted the ornithological interest of the atoll, which was recognized as an Important Bird Area for its breeding seabirds and migratory waders (Rocamora and Skerrett 2001). Following an earlier visit, Skerrett (1996) suggested that Cosmoledo had Seychelles' largest population of breeding Red-footed Booby Sula sula and Masked Booby Sula dactylactra, and was also probably the only remaining breeding site in Seychelles for Brown Booby Sula leucogaster. Information gathered in 1990 and 1991, the only two years Sooty Tern Sterna fuscata eggs have been collected from Cosmoledo in recent years, suggested that the Sooty Tern population breeding on Grand Ile was the largest in Seychelles (A. Constance pers. comm., E.G. Smith in litt. to C. Feare in Mortimer and Constance 2000).

In addition Cosmoledo hosts at least three subspecies of landbird endemic to the Aldabra group: Souimanga Sunbird Nectarinia (sovimanga) buchenorum, Madagascar White-eye Zosterops maderaspatana menaiensis, and Madagascar Turtle Dove Streptopelia picturata ssp. However, the taxonomic status of all three is 
uncertain and requires further investigation. Cosmoledo also supports a population of Madagascar Cisticola Cisticola cherina (Benson 1970, Sinclair and Langrand 1998).

The isolation of Cosmoledo has conferred some protection from human interference. In addition, seas are rough at the height of the south-east monsoon and this reduces access, but the atoll is increasingly visited at other times by both fishing and tourist boats. Small settlements have existed on both Menai and Grand Ile but neither island is now permanently occupied. These earlier colonisations have, however, left their mark in terms of exotic vegetation and, more important from the birds' point of view, introduced mammals, notably rats and cats.

In order to investigate further the status of the breeding avifauna of Cosmoledo, an expedition was conducted by the authors from 20 to 23 June 1999 with the support and assistance of the Islands Development Company, managers of the atoll, and the Division of Environment, Seychelles Government. This was the first documented ornithological expedition to the atoll during the south-east monsoon, which is the main breeding period for Red-footed Booby, Brown Booby and Sooty Tern.

\section{Methods}

Study area

The western Indian Ocean, including Cosmoledo, experiences two climatic seasons, the drier south-east monsoon from May to October, and the more variable but wetter north-west monsoon from December to March (Walsh 1984). Cyclones are rare in the Aldabra group (Walsh 1984). Some of the seabirds are markedly seasonal in their breeding but the mechanisms influencing these breeding seasons are not fully understood. In some species, differences may be related to seasonal changes in ocean currents (Diamond and Prys-Jones 1986). The boundaries between currents may generate fronts where an increase in plankton attracts feeding shoals of fish and, in turn, seabirds that feed on the fish. Such a boundary exists between the South Equatorial Current and the Equatorial Counter Current at $6-7^{\circ} \mathrm{S}$ during the south-east monsoon, shifting to around $9-10^{\circ} \mathrm{S}$ during the north-west monsoon (Piton and Magnier 1975).

Menai, at the west of the atoll (Figure 1 ) is $c .3 .5 \mathrm{~km}$ long and $50-500 \mathrm{~m}$ wide. It consists of heavily dissected reef limestone ("champignon"), with sand-dunes along much of the seaward edge rising up to $15 \mathrm{~m}$. Littoral vegetation is dominated by Scaveola taccada, Tournefortia argentea and Suriana maritima. Much of the interior is covered by Pemphis acidula, Sideroxylon inerme, Ficus spp. and other indigenous species, and coconut and Casuarina woodland are present primarily around the abandoned settlement. Dense mangroves of at least six different species (Bayne et al. 1970) extend up to $800 \mathrm{~m}$ into the lagoon. Ile du Sud-Ouest, at the south of the atoll, is an elongated island $3 \mathrm{~km}$ long and $50-200 \mathrm{~m}$ wide, almost completely covered by "champignon", which makes access to the interior difficult. There is a narrow band of sand and rock all along the seaward side permitting easier walking along the length of the island. The vegetation is dominated by low (0.5-2 $\mathrm{m}$ high) bushes of Pemphis of variable density, with littoral 
vegetation similar to Menai also present. On the lagoon side, there are some areas of mangroves 3-6 m high, separated by outcrops of raised undercut cliffs and a few small sandy beaches. Grand Ile (called Wizard Island on older maps and charts), on the south-east of the atoll, is c. $3.2 \mathrm{~km}$ long and $0.3-1.1 \mathrm{~km}$ wide. The most conspicuous physiographical feature is the ridge of dunes along the seaward coast (and the windward side during the south-east monsoon), rising to $c .17 \mathrm{~m}$ in the north but progressively lower towards the south of the island. Inside the dunes is an extensive sand and gravel flat, while along much of the lagoon-side of the island is a ridge of sand, $3-5 \mathrm{~m}$ high in places. The dominant vegetation of the seaward dunes is dense Tournefortia argentea, which also occurs in clumps in the central plain and on the lagoon-side ridge. Suriana maritima and Scaevola taccada appear at lower elevations on the seaward dunes, and the latter is more widespread at the north of the island and on the north-west peninsula. The central plain comprises a mosaic of scrubby vegetation and extensive patches of grassland, while over the southern half of the island scrub is more prevalent and grassland correspondingly reduced. On the sandflats at the foot of the tall northern dunes is a small grove of coconut Cocos and sisal Agave, where a former settlement was apparently based (Bayne et al. 1970). On the north-west peninsula a group of buildings, now largely derelict, was constructed in 1990-1991 to facilitate the handling and storage of Sooty Tern eggs prior to their export to Mahé (see below).

\section{Study sites}

We landed on the five islands of the atoll known to support important populations of birds (Bayne et al. 1970, Benson 1970, Skerrett 1996, Mortimer and Constance 2000) and circumnavigated the others using a small boat. On 20 June we visited Ile Nord-Est, Ile du Nord and Menai (where we spent three hrs), and circumnavigated all eight islets in-between. Late that same day three observers (MA, GR and AS) landed on Ile du Sud-Ouest and two (CF and EG) on Grand-Ile to conduct standardized seabird censuses over the next three days. On 23 June, we circumnavigated the six small islands and islets between Ile du Sud-Ouest and Ile du Trou.

Detailed censuses were conducted on Ile du Sud-Ouest (for boobies) and Grand Ile (Sooty Terns), which host the largest colonies of breeding seabirds. Direct counts of all species of birds seen were made on Menai, Ile du Nord and Ile Nord-Est where we landed. On the smaller islands and islets that were circumnavigated counts were made from a boat, using binoculars (except Ile aux Chauve-Souris due to tide and time constraints).

\section{Booby census and breeding chronology}

Nests or occupied sites (see below) of all three species of breeding boobies present on the atoll were counted during our survey. However, very few Masked Boobies had active nests at this time of year, whereas Red-footed Boobies, and perhaps also Brown Boobies, were at the peak of the breeding season. Nests on Ile du Sud-Ouest, where the main booby colony occurs, were scattered in subcolonies across the entire island, and mapping the colony was not a practical option 
due to the presence of hazardous "champignon" which rendered walking difficult on most of this island, as was the use of circular sample plots. Transects were therefore employed and were systematically positioned along the length of the island at $200 \mathrm{~m}$ intervals measured by GPS, using the easier access of the southern shoreline. A total of 15 transects perpendicular to the beach were laid out across the entire width of the island, and classified into two habitat types: Pemphis-dominated vegetation $0.5^{-2} \mathrm{~m}$ high and of variable density; and mangrove-dominated vegetation 3-6 $\mathrm{m}$ high. Transect length was measured by GPS and varied between 40 and $190 \mathrm{~m}$ depending on the shape of the island. As it was impossible to walk along straight strip transects, we counted all nests present between two markers tied $15 \mathrm{~m}$ apart on a cord stretched between $2.5 \mathrm{~m}$ poles. A third marker was at the centre of the cord. Poles were held by observers who walked in tandem and called out all nests or nesting sites found on his side of the central marker to be recorded by a third observer.

This arrangement allowed greater flexibility in negotiating difficult areas of "champignon" and impenetrable vegetation, the poles being moved one way or the other as required, without having to follow a straight line. Nests with eggs, chicks or adults present on or nearby the nest were recorded for Red-footed Boobies, whereas Apparently Occupied Sites (Nelson 1978, Wanless 1987, Lloyd et al. 1991) corresponding to all obvious nesting sites (including pairs showing fidelity to a particular site without an egg or a chick) were recorded for the ground-nesting Masked Boobies (which use no nesting material) and Brown Boobies (which use some nesting material). Nest densities were calculated in both habitat types and used to produce population estimates with confidence intervals for the entire island. The total area covered by breeding habitats was estimated from measurements made with the GPS when positioning the transects (total length of the island multiplied by average length of transects across the island).

In order to investigate the breeding chronology of Red-footed Booby, each nest was classified under one of the following breeding stage categories: empty (with adult present), egg, very small chick (no or little down, less than one week), small chick (mostly to completely covered in down, less than one third of adult size, 1-3 weeks), large chick (covered in down, more than one third of adult size, 4-6 weeks), very large chick (partly feathered, 7-11 weeks), close to fledging (fully feathered, 12-17 weeks). These categories were determined from plumage development and chick size as per Nelson (1978). The hatching chronology of the colony was determined from the number of nests of each category sorted into periods of 15 days. Laying chronology was derived using a mean incubation period of 45 days (Nelson 1978), although such calculations could not take into account nests that failed before our visit. Fledging peaks were predicted using an average fledging period of 120 days (Nelson 1978), assuming that all nests observed would be equally successful between the different categories. Wherever possible, adults sitting on a nest were lifted with a pole to check the nest contents. However, where this was not possible (240 in total) nests were classified as "Sitting adult" and their contents estimated, using the ratio of those sitting on eggs to those brooding young observed among other nests.

Direct counts of adult boobies or occupied nests were conducted on other islands, which host much smaller numbers of boobies compared with Ile du Sud-Ouest, so that population estimates of nesting pairs could be produced for 
the whole atoll. Counts of adult Red-footed Boobies were calibrated to the number of nests in several subcolonies and later converted into occupied nests.

\section{Sooty Tern census and breeding chronology}

The perimeter of the colony on Grand Ile was traced using a hand-held GPS and the outline was also drawn on an existing map of the island (Republic of Seychelles, 1:25000, Edition 1-DOS, 1979). The area of the colony was obtained by drawing the outline on high-quality paper. This outline was cut out, together with a square of the same paper representing $1 \mathrm{~km}^{2}$, and the masses of each were measured on a balance accurate to $0.01 \mathrm{~g}$. Dividing the weight of the paper representing the colony by the weight of the paper representing $1 \mathrm{~km}^{2}$ therefore gave the area of the colony in $\mathrm{km}^{2}$.

Estimates of the density of nests were obtained by walking $360^{\circ}$ around a post, positioned randomly, with a string $1.78 \mathrm{~m}$ long, and counting all eggs (Sooty Terns lay one egg) over which the string passed. This provided a count of the number of nests $/ 10 \mathrm{~m}^{2}$. In all, 60 samples were taken, distributed among habitats in proportion to their areas. Nest density was measured in the four main habitats occupied by Sooty Terns. These were: areas of dead grass within open Tournefortia bush $<3 \mathrm{~m}$ tall, at the north of the island; areas dominated by dry grasses, with some Boerhavia, towards the northern end of the central plain; areas in the centre of the colony dominated by dry grasses, with some Boerhavia, within open Tournefortia bush $<1 \mathrm{~m}$ tall; and beach crest along the eastern coast, with sparse dry vegetation within open Tournefortia bush $<1 \mathrm{~m}$ tall.

\section{Results}

Booby census and breeding chronology

Results for Ile du Sud-Ouest were derived from a total transect area representing $7.5 \%$ of the island, where Pemphis-dominated habitat (11 transects totalling 1,350 $\mathrm{m}$ length and $2.02 \mathrm{ha}$ ) and mangrove-dominated habitat (four transects totalling 170 m length and 0.25 ha) were well represented. The ratio between Pemphis and mangrove habitats within our sample was estimated to be roughly the same for the entire island and was used to calculate their total area (26.6 ha and 3.4 ha respectively out of 30.0 ha of available breeding habitat on the entire island).

\section{Red-footed Booby}

A total of 993 nests were counted in the 1,520 m of transects on Ile du Sud-Ouest. Nests were found on Pemphis bushes 1-2 $\mathrm{m}$ high, and on mangroves 2-6 $\mathrm{m}$ high. They were scattered all along Ile du Sud-Ouest, most often clustered in dense patches where nests were 1-3 $\mathrm{m}$ apart, with large empty areas of apparently suitable habitat between them. There seemed to be a higher density of nests on the northern side of the island (more sheltered from strong south-east winds) and particularly along the raised "champignon" coastline of the lagoon, from where birds may have found it easier to land and take off. The density of nests per hectare $( \pm 95 \%$ confidence limits) was significantly higher in mangroves 
$(1,085 \pm 395)$ than in Pemphis $(323 \pm 116 ; t=-5.031, d f=13, P=0.027)$. Taking into account their respective habitat areas, Pemphis and mangrove habitats hosted $8,579 \pm 3,094$ and 3,687 $\pm 1,343$ occupied nests respectively, giving a total population of 12,266 \pm 4,437 nesting pairs of Red-footed Boobies for the entire island. This has been added to estimates for other islands with smaller populations to produce totals for the entire atoll (Table 1). Among the other islands, Ile NordEst, Ile du Nord, Menai, Ile aux Chauve-Souris, Pagode and Ile du Trou had small colonies of several hundreds of nesting pairs. Elsewhere numbers were relatively insignificant. A total population of around 15,000 nesting pairs (10,000 to 20,000 taking into account the estimate's uncertainties) is considered reasonable for the entire atoll at this time of year (Table 1 ).

Of the 753 Red-footed Booby nests for which breeding stage was recorded on Ile du Sud-Ouest, $92.2 \%$ had chicks (only $4.5 \%$ of nests had eggs, the others being empty). All these chicks except two had no feathers and were therefore considered less than 7 weeks old (Nelson 1978; our categories "very small", "small" or "large"), indicating that our visit coincided with the first half of the main chick-rearing period of the colony. Hatching was estimated to have occurred between early May and our visit (20-23 June) (Figure 2), suggesting a main egglaying period between mid-March and mid-May, with two sharp peaks during the second half of March and the first half of May. Most fledging was subsequently predicted between early September and end of October. A small percentage $(3.2 \%)$ of occupied nests were empty, probably representing pairs that had not yet laid. There were no fledged juveniles on or near nests on Ile du Sud-Ouest at the time of our visit, although some were seen flying around or on the ground mainly on the northern side of the colony. On Ile du Nord and Ile du Nord-Est, pairs had chicks at various stages or an egg, but very few juveniles were observed.

\section{Masked Booby}

A small number of breeding birds (173 pairs from direct count and 32-208 pairs estimated from our transects), were present on Ile du Sud-Ouest, mainly on the southern half of the island in areas with bare ground. Many non-breeding birds (probably a few thousand) were also present on this part of the island, roosting on the ground or in flight in the vicinity and being harassed by frigatebirds Fregata spp. On Ile du Nord and Ile Nord-Est, 250 pairs were estimated to be present on each island (Table 1 ). Smaller numbers of nesting pairs were present on Pagode, Goëlettes and Ile du Trou, and a few pairs on an unnamed island near Ile Nord-Est. In total, not more than 1,00o pairs were found nesting on the atoll at this time of year. Most of these nesting pairs appeared to be at the very early stages of their breeding cycle. On Ile du Sud-Ouest, six of the nine nests found in our transects had eggs, two were empty and one had a recently hatched chick. On Ile du Nord, only two pairs had eggs and one had a feathered chick, the remaining pairs being present but not yet with eggs.

\section{Brown Booby}

Between 30 and 50 pairs of Brown Booby were estimated to be present on Ile du Sud-Ouest, scattered across the island in small groups of one to three nests. Six 


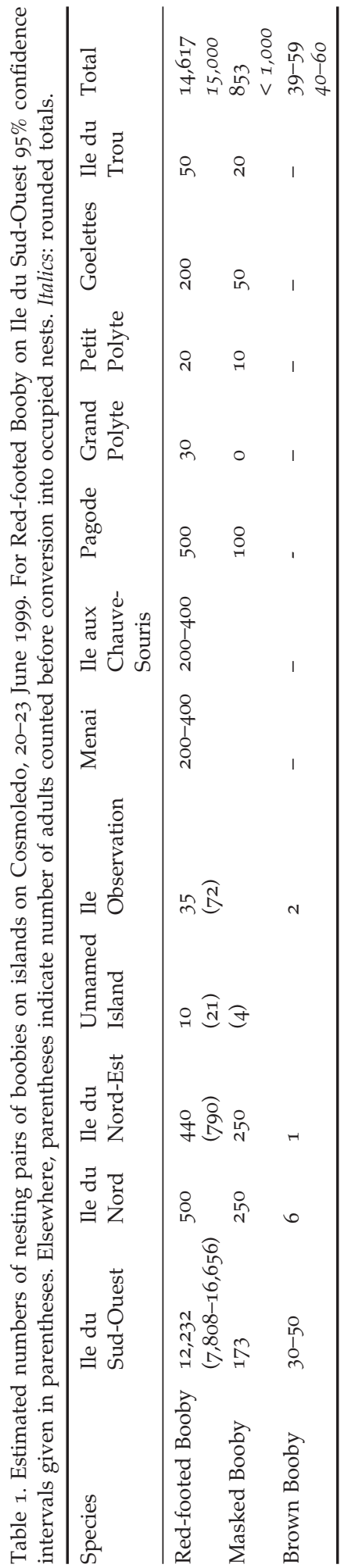




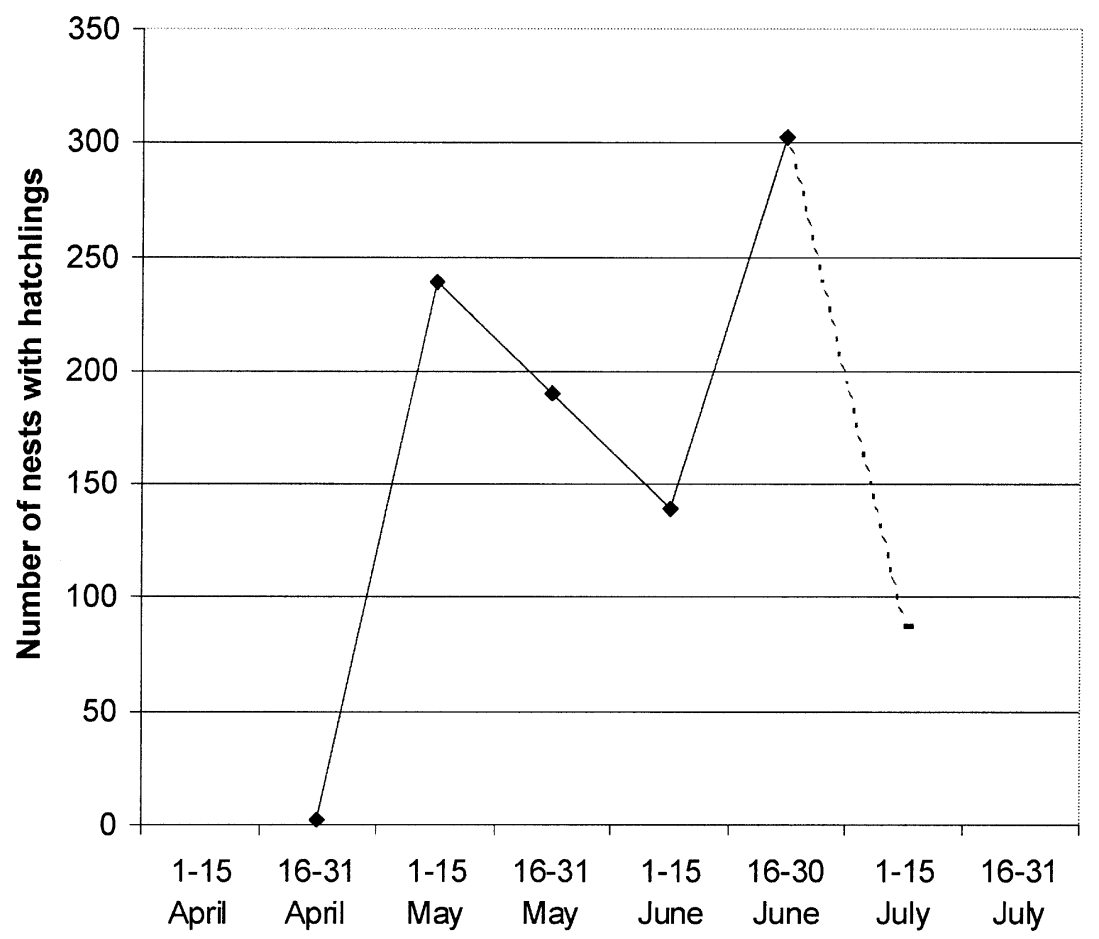

Figure 2. Estimated hatching chronology of the Red-footed Booby on Cosmoledo Atoll (derived from ageing of chicks during a single visit on 20-23 June 1999, see text).

nesting pairs were found in a single location on Ile du Nord, and three additional pairs, each with an extra bird that may have been a subadult (one on Ile NordEst, one on Ile du Trou and one on Ile du Sud-Ouest), were also recorded. Of 13 nests found, six had eggs, one a recently hatched chick and three were occupied by birds probably about to lay, indicating peak laying in May/June, hatching in June/July and fledging in September/October (assuming $c$. five months from laying to fledging (Nelson 1978). Three other nests had grown chicks (one "small", one "large" and one "feathered"). Nests with eggs had an average clutch of 2.17 eggs (three with two eggs, two with three eggs and one with one egg).

\section{Sooty Tern}

The area of the Sooty Tern colony on Grand Ile in 1999 was estimated as 35.0 ha. Nesting birds were confined to the northern part of the island. Most were on flat grassy areas that dominated this part of the island, and especially in areas of beach crest on the northern peninsula and eastern beach ridge where Tournefortia bush $(<1 \mathrm{~m})$, with open areas, predominated. Nesting also occurred on higher dunes on the eastern coast.

During the time available, it was not possible to map vegetation, but the number of samples of nest density taken in each habitat roughly reflected the 
Table 2. Nest density in the four main habitats occupied by Sooty Terns on Grand Ile, Cosmoledo.

\begin{tabular}{lllll}
\hline Habitat & $\begin{array}{l}\text { Dead grass / } \\
\text { Tournefortia } \\
\text { bush, N end } \\
\text { of colony }\end{array}$ & $\begin{array}{l}\text { Grass/ } \\
\text { Boerhavia } \\
\text { at N of } \\
\text { central plain }\end{array}$ & $\begin{array}{l}\text { Boerhavia/grass, } \\
\text { among } \\
\text { Tournefortia, } \\
\text { centre of colony }\end{array}$ & $\begin{array}{l}\text { Beach crest, east } \\
\text { coast, open } \\
\text { Tournefortia } \\
\text { bush }\end{array}$ \\
\hline Mean nest density/10 m ${ }^{2}$ & 35.6 & 28.6 & 43.5 & 28.2 \\
$95 \% \mathrm{CI}$ & 3.5 & 3.5 & 3.5 & $5 \cdot 7$ \\
$n$ & 20 & 10 & 10 & 20 \\
\hline
\end{tabular}

area occupied by that habitat within the colony. To estimate the number of pairs in the colony therefore, the overall mean of the 60 nest density samples $(33.3 \pm$ 2.3 nests $95 \% \mathrm{CI}$ ) $/ 10 \mathrm{~m}^{2}$, was used (Table 2). Combining this with the estimated area of the colony produced a colony size of $1,165,500$ pairs, with $95 \%$ confidence limits giving a range of $1,081,500-1,249,500$ pairs (based only on the nest density measurements; no error estimate was obtained for colony area).

Parts of the northern end of Grand Ile were clearly unsuitable for nesting Sooty Terns, e.g. the grove of coconut trees and sisal. The northern high dunes along the eastern coast were also unoccupied, while dunes further south did support nesting birds on their tops and on the less steeply sloping parts of the western side. Along the northern coast, a triangle of tall grass was devoid of birds, possibly because it was too dense and tall. Further south, a grassy area in the centre of the island was also largely unoccupied, although here there were small, localized pockets of nesting Sooty Terns. Although the grass was dense here, much of it was flattened and in an area of $c .40 \mathrm{~m} \times 10 \mathrm{~m}$ eggs had been deserted. There were some dead adults in this area, some with breast muscles eaten. Footprints of cats were seen on the beach on both the eastern and western shores and these are likely to have been the predators responsible for these deaths. No ticks were seen during the handling of 850 adults during ringing, and 14 Cattle Egrets Bubulcus ibis that were seen in the colony may have taken eggs, but are unlikely to have been responsible for these desertions.

During this visit all nests in the colony contained eggs, but on 21 June large numbers of eggs towards the southern end of the colony and on nearby high dunes began to hatch. Sooty Tern eggs are incubated for c. 28 days (Feare 1976a), indicating that laying began in the Grand Ile colony around 24 May. At the northern end of the colony, most eggs that were broken contained welldeveloped embryos, suggesting that Sooty Terns in this colony nested synchronously, as elsewhere in the Seychelles (Feare 1976a).

\section{Other seabirds and waterbirds}

Significant findings were the presence of a small colony of Greater Frigatebirds Fregata minor (eight nests: six empty, one with egg and one with eggshells) on Ile du Sud-Ouest and the presence of four pairs of White Terns Gygis alba apparently occupying nesting sites in the mangroves (plus three individual birds). The latter has not yet been confirmed as breeding on Cosmoledo. Other terns were found in relatively small numbers on various islets around the atoll (Table 3 ) but no courtship or breeding was seen. A few Red-tailed Tropicbirds Phaethon rubricauda 
Avifauna of Cosmoledo Atoll

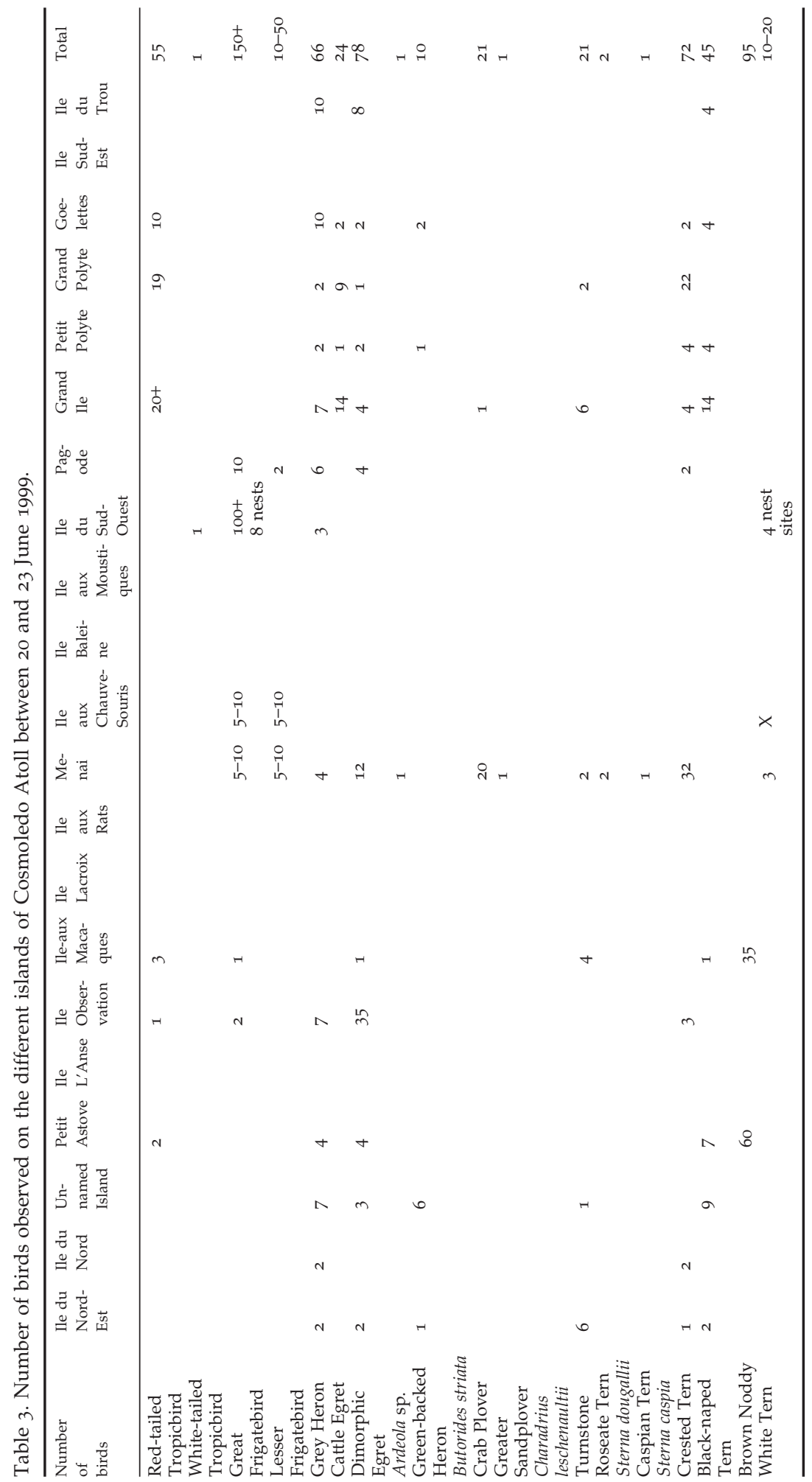


were seen on the small islands, and on Grand Ile singles and pairs were seen flying over the eastern high dunes throughout the day, sometimes landing among the Tournefortia, but no nest sites were found. A single White-tailed Tropicbird Phaethon lepturus was seen on Ile du Sud-Ouest. Some Lesser Frigatebirds Fregata ariel were also observed in small numbers and, along with Greater Frigatebirds, harassed Masked Boobies.

Grey Herons Ardea cinerea and Dimorphic Egrets Egretta dimorpha were widely distributed, in small numbers, among the islands. Cattle Egrets were present on some of the eastern islands, and an unidentified pond heron (Ardeola sp.) that was seen on Menai, was a first record for Cosmoledo.

\section{Landbirds}

All five species of landbirds previously known from Cosmoledo were recorded during our expedition, but none were abundant. Madagascar White-eye was confined to Menai, and Madagascar Turtle Dove to Ile du Sud-Ouest, as previously recorded (Mortimer and Constance 2000). Pied Crows Corvus alba were seen only on Menai and Ile du Nord-Est.

The turtle dove was always found on the ground, foraging among grasses between "champignon" or under the thick bushes that cover most of Ile du SudOuest, but not in mangroves or the few other trees present on the island. Despite their ability to fly over $100 \mathrm{~m}$., as we observed on one occasion, they were extremely reluctant to take off when chased, and preferred to run and take refuge under the thickets, sometimes with a few wing beats but always keeping very close to the ground. Though uncommon, we found them all across the island in small groups of one to four birds, and recorded up to six birds feeding in an open area of bare ground and rock sparsely covered with short grass. Photographs and plumage description of the two turtle doves caught revealed interesting differences of coloration from specimens of Streptopelia picturata coppingeri found on Aldabra; these will be described elsewhere.

Souimanga Sunbirds were seen on most islands and even small islets, and were numerous on Menai, Grand Ile, and Ile du Sud-Ouest. On Grand Ile they were seen mainly in dense Tournefortia on the eastern dunes. On Ile du SudOuest, the species was found in Pemphis habitat of variable density. The most widespread of the landbirds both in terms of the number of islands on which they occurred and the number of habitats in which they were found, was Madagascar Cisticola. On Grand Ile, it occurred in bushes on the high dunes, in the coconut and sisal groves, and throughout the mosaic of grass and bushes that dominated the northern third of the island. On Ile du Sud-Ouest it seemed, however, to be less abundant than the sunbird.

\section{Discussion}

\section{Boobies}

With an estimated 15,000 pairs at the time of our visit (10,000-20,000 taking into account uncertainties), Cosmoledo probably holds the largest Red-footed Booby colony in the Indian Ocean. The nearest colony (Aldabra) was estimated to sup- 
port 6,000-7,000 breeding pairs in 1967-1968 (Diamond 1971, 1974). A recent census by Burger and Betts (2001) in March 2000 suggested that the colony had increased, though differences in the time of counts and census methods make comparisons difficult. The only other colony in Seychelles is 50-70 pairs on South Island, Farquhar Atoll (Rocamora and Skerrett 2001). Elsewhere in the western Indian Ocean there are colonies at Tromelin Island (130-18o pairs; Le Corre 1996) and Europa (2,800-3,800 pairs; Le Corre and Jouventin 1997a). The Chagos archipelago as a whole supports $c$. 11,00o pairs, the largest colony at Danger Island hosting 3,470 pairs (Symens 1999). Other important concentrations in the Indian Ocean are Christmas Island (12,000 pairs) and Cocos (Keeling) Islands (c. 30,000 birds, probably less than 12,000 pairs; Carboneras 1992). The taxon in the Indian Ocean (S. s. rubripes) extends to islands in the central and western Pacific, where colonies are smaller. The global population of this taxon is around 60,000 pairs (Schreiber et al. 1996), of which Cosmoledo therefore houses c. 25\%. On Genovesa, Galapagos, a colony of 140,000 pairs is of the eastern Pacific subspecies $S$. s. websteri. Cosmoledo probably supports the largest colony of S. s. rubripes in the world. This preliminary figure of 15,000 pairs derived from a single annual count should, however, be considered as a minimum estimate as the species is known to breed year round, with a breeding cycle of c. 6 months and a long period of post-fledging parental care, generally c. 6 months but sometimes more (Diamond 1974, Nelson 1978). Our census could not take into account birds that had laid between July and December 1998 (flying juveniles were few and dispersed in the colony), plus those that had failed their breeding attempt before the census (an interval of $c$. 35 weeks being needed before a second nesting attempt; Nelson in litt. to Diamond 1974).

During a brief visit in November 1998, nesting Masked Boobies were much more abundant than the $c$. 1,000 pairs present in June 1999 (AS pers. obs.). Following a previous visit on 12-13 April 1996, the total breeding population of the atoll was estimated at 5,000-6,000 pairs (Skerrett 1996, Rocamora and Skerrett 2001). The race on Cosmoledo is $S$. $d$. melanops, which is restricted to islands of the western Indian Ocean and has a global population of around 10,000 pairs, of which Cosmoledo therefore houses over 50\%. Masked Boobies are widespread in the Indian Ocean but appear to form smaller and fewer colonies than Red-footed Boobies. Cosmoledo thus hosts the largest colony of Masked Boobies in the western Indian Ocean, the only other important colony of c. 3,000 pairs on Boudeuse in the Amirantes (Skerrett 1995, Rocamora and Skerrett 2001). The Boudeuse colony is periodically exploited (illegally) for both adults and young (Feare $1978 \mathrm{~b}$ ), so Cosmoledo must be regarded as the main safe stronghold of this subspecies. The large population of "Masked" Booby (25,000-50,000 pairs) on Galapagos has now recently been ascribed to a separate species, Nazca Booby Sula granti (Pitman and Jehl 1998, Roberson 1998).

The very low numbers of Brown Boobies present on Cosmoledo may simply reflect the western limit of the Indian Ocean distribution of this species, that has never been recorded as common in Seychelles and the taxon involved, S. l. plotus, is much more abundant towards the east of its range in eastern Indonesia and the western Pacific. In the former it has suffered serious declines (de Korte 1991). Mortimer and Constance (2000) provided the first reliable evidence that Brown Boobies nest on the atoll. These authors mention its greater abundance in the 
past and its presence as a breeder also on Pagode and Goëlettes, and in 1976 Brown Boobies also nested on small islets in Farquhar Atoll and on Desnoeufs Island, Amirantes (CJF pers. obs.), from all of which they have now disappeared (CJF and AS, pers. obs). In 1973 Brown Boobies were nesting on islets off northwest Madagascar, with 100 and 250 adults estimated on two islets respectively (Polunin 1979).

Since this is the first complete census of boobies on Cosmoledo, it is not possible to report trends. However, it is certain that major changes in habitat, especially those associated with the extraction of guano and the planting of coconuts, and the generalized and often unsustainable exploitation of seabirds for eggs and meat, have provoked a severe decline in western Indian Ocean booby populations (Feare 1978a, Diamond 1994). Several colonies of Red-footed Booby (Astove, Assumption, Saint-Pierre, D'Arros, Platte, Providence and Saint-Joseph and, outside the Seychelles, Agalega, St Brandon and Rodrigues), Masked Booby (Assumption, Etoile, Bird Island) and Brown Booby (Desnoeufs and possibly Bird Island), were extirpated during the last two centuries (Feare 1978a, Cheke 2001). Cosmoledo was permanently inhabited from the 1850 os up to the late 1980 s and its colonies were also affected by harvesting (Mortimer and Constance 2000). However the colony of Ile du Sud-Ouest may have been to some extent protected by its difficult terrain. Despite the occurrence of some poaching from uncontrolled fishing vessels since the abandonment of the settlement in 1992, it is possible that these colonies have increased since the 1970s, when the regular harvesting of at least some of them was stopped or greatly reduced. Although Diamond (1974) found Red-footed Boobies breeding on Grand Ile, none were seen there during this visit.

Although we sampled a significant percentage of Ile du Sud-Ouest (c. $7 \%$ ), our limited number of transects $(n=15)$ resulted in some uncertainty in induced population estimates. This should be improved in future censuses by increasing the number of transects while reducing their length (e.g. $n=30$, equivalent to one every $100 \mathrm{~m}$ ). Alternatively, if flights could be organized from Astove or Assumption, aerial photography could be tested to census the boobies. This method has proved to be efficient for other sulids (e.g. Northern Gannets Morus bassanus, Siorat and Rocamora 1995). However, some sampling on the ground would always be required to determine the proportion of nests of each species, and to detect the scarcer Brown Booby.

The scarcity of frigatebirds on Cosmoledo may also explain the large numbers of Masked Boobies found there. Both species of frigatebird used to nest in greater numbers (at least several hundreds pairs of each species) a few decades earlier on Cosmoledo (A. Constance pers. comm.), whereas today only several hundred individuals and a small breeding colony of Greater Frigatebirds is present. In February 1970, Gillham (1977) recorded several hundred frigatebirds kleptoparasitizing boobies on Grand Ile and 40-50 on Pagode. On Cosmoledo we observed that frigatebirds clearly prefered kleptoparasitizing Masked over Red-footed Boobies, probably because the former regurgitated their food as soon as they were attacked. Le Corre and Jouventin (1997b) also considered that Red-footed Booby was better able to withstand frigatebird kleptoparasitism than Masked Boobies. It is therefore possible that the existence of a large Masked Booby popu- 
lation on Cosmoledo is due to the absence of large frigatebird colonies, in contrast to Aldabra where Masked Boobies are absent.

Red-footed Booby is known to breed all year round (Diamond 1974, Nelson 1978) but in Seychelles there seems to be a main laying season during the northwest monsoon (November to May), followed by a second minor "wave" during the south-east monsoon (June to October). During earlier brief visits, Red-footed Boobies were breeding on Cosmoledo in very large numbers in April 1996 (many incubating or with chicks) but less densely in the last week of November 1998 (AS pers. obs.), which appears consistent with the seasonal pattern described above. On Aldabra, during two consecutive breeding seasons (1967-1969), the main colony laid between November and February but other birds also laid in August and September at Bras Takamaka (Diamond 1974). Between 12 and 20 March 2000, Burger and Betts (2001) found more than $80 \%$ of the nests with eggs (with perhaps a few that had recently hatched chicks), indicating a laying peak between the end of January and 15 March. Diamond reported differences in breeding chronology between colonies at Cosmoledo from a visit in March 1968 where he noted that birds on Menai were halfway through a breeding cycle whereas those from Grand Ile were just beginning one. We did not investigate nor notice such marked differences between the different island colonies visited. The existence of a main laying season during the north-west monsoon on Aldabra was attributed by Diamond (1974) to the presence of a large frigatebird population nesting with the boobies on the main colony. However, this explanation does not hold for Cosmoledo. On Tromelin, the species does not breed seasonally (Le Corre 1996).

The breeding cycle of Masked Booby differs from that of Red-footed Booby. Most breeding pairs appear to lay during the south-east monsoon and only a minority during the north-west season, as observed in June 1999 (less than 1,000 pairs) and in April 1998. This pattern also applies to Masked Boobies on Boudeuse and Desnoeufs islands in the Amirantes (Feare 1978b). Brown Boobies show a variable breeding chronology with pairs at all breeding stages possible throughout the year. Mortimer and Constance (2000) reported the presence of several pairs with small chicks or juveniles in December 1996. Ten of the 13 pairs we recorded were beginning their breeding cycle in June 1999. From this limited number of observations, the main laying period for the species appears to be between April and June.

The absence of rats and cats from Ile du Sud-Ouest (Mortimer and Constance 2000) was confirmed by our observations, as we saw no signs of them during our stay (two baited rat traps remained permanently set up near our campsite). Introduced rabbits (reported by Mortimer and Constance) were observed on a few occasions but do not appear to be a threat to the seabirds, although they may have some impact on vegetation.

\section{Sooty Terns}

At just over one million pairs, the colony on Grand Ile is the largest in Seychelles. Recent estimates of the populations of other major colonies are: Bird Island $c$. 700,000 pairs, Desnoeufs c. 500,000 pairs (both CJF unpubl. data) and Aride $c$. 
300,000 pairs (J. Bowler pers. comm.). Claims that the Grand Ile colony sometimes occupies the whole of the island (Mortimer and Constance 2000), and then may be larger than the 1999 estimate, remain to be substantiated. Elsewhere in the western Indian Ocean, only the colony on Europa, in the Mozambique Channel, at $c$. 1,000,000 pairs (Le Corre 2001), approaches that on Grand Ile. (Le Corre and Jouventin 1997a). A colony of 200,000-300,000 pairs breeds on Serpent Island, Mauritius (Safford 1993), but the formerly large colony (hundreds of thousands, Williams and Rowlands 1980) on St Brandon has now declined to $c .20,000$ pairs (Swinnerton et al. 1996). Although the taxon that breeds in the Seychelles, S. f. nubilosa, ranges from the East African coast east to the Ryukyu Islands of Japan, the colonies in the Seychelles, Mauritius and Europa are considerably larger than those further east and constitute the main centre of distribution of this subspecies. The global population of this taxon is estimated at around 4.5 million pairs (CJF unpubl. data), with Cosmoledo holding c. $20 \%$ of these.

The synchronous breeding of Sooty Terns on Grand Ile in late May-early June corresponds with breeding seasons elsewhere in the Seychelles, where the onset of breeding appears to be related to factors associated with the start of the southeast monsoon (Ridley and Percy 1958, Feare 1976a). Further south, in the Mozambique Channel, Sooty Tern breeding seasons differ, with birds in Iles Glorieuses breeding in most months (Benson et al. 1975), and those on Juan de Nova in the austral summer (M. Le Corre pers. comm.), while those on Europa breed at the same time as those in Seychelles (Le Corre 2001). On St Brandon (Cargados Carajos), colonies appear to show breeding activity at all times of year, with different colonies at different stages and some with all stages of breeding present at one time (Newlands 1976, Williams and Rowlands 1980). Staub and Gueho (1968) identified two peaks of breeding activity on St Brandon, a smaller one in November-December, and the main one in the "winter" (presumably JuneJuly).

During the June 1999 visit to Grand Ile we found no evidence of egg collection by visiting boats. The absence of human footprints on the beaches indicated that there had been no recent visitors, and the colony may be protected from such visits by the rough seas that characterize the south-east monsoon period. A small infrastructure was built in the early 1990 s by the Islands Development Company to facilitate the commercial harvest of eggs. This was intended to supplement the existing harvest from Desnoeufs Island (Feare 1976b), but after two seasons of collecting (1990 and 1991) the operation was found to be uneconomic. In the 1920 and 1930s, however, when large numbers of Sooty Tern eggs were collected in order to satisfy an export market for the yolks (Ridley and Percy 1958), the huge harvests reported to have come from the Amirantes most likely included a substantial contribution from Cosmoledo (Feare 1976b).

Rats (probably Rattus rattus) have been reported to occur on Grand Ile (Christiansen 1944, Mortimer and Constance 2000 and J.A. Mortimer pers. comm.), but no signs of rats were seen during this visit despite searches for droppings and footprints, and the setting of a baited trap at our campsite. The presence of ample food, in the form of birds' eggs, at this time of year may have led rats to remain in the Sooty Tern colony. The apparent decline in the numbers of rats on Grand Ile, which according to Christiansen (1944) were extremely abundant and ate so many Sooty Terns that the birds left the island, may have 
followed the vacation of the island by human settlements. Cat footprints were seen on the beaches, and several corpses of adult Sooty Terns, which had probably been taken by cats, were found in an area of the colony that had been deserted by nesting birds. Cats had been reported on Grand Ile in 1970 by Gillham (1977) and in 1968 by Diamond (in Bayne et al. 1970). Cattle Egrets were seen in the Sooty Tern colony and may take eggs and small chicks, and kleptoparasitize larger chicks as elsewhere in the Seychelles (Feare 1975). It is surprising that Pied Crows were not seen on Grand Ile, since the abundance of eggs might be expected to constitute an attraction for this species. However, numbers on Cosmoledo appeared small and during the time of year when Sooty Terns are absent, there may be insufficient food on Grand Ile to support a population of crows. This may also account for the apparent absence of rats on Grand Ile, and for the highly localized predation by cats.

\section{Other seabirds and waterbirds}

During our visit the only other seabirds recorded breeding were Greater Frigatebirds, with a small colony on Ile du Sud-Ouest, a colony also reported by Mortimer and Constance (2000). Frigatebirds appear to have been more numerous in the past and Vesey-Fitzgerald (1941) recorded them nesting on islets in the lagoon. None were seen doing so on our visit. Like Mortimer and Constance (2000), we were unable to visit the mangroves on Menai, where Constance reported that large numbers used to nest.

Tropicbirds were scarce on Cosmoledo, in contrast to Aldabra, where around 2,000 pairs each of Red-tailed and White-tailed Tropicbirds breed (Betts 2000). No nests were found on Cosmoledo, although Bayne et al. (1970) reported an unpublished account (with no details) of nesting by Red-tailed Tropicbirds in March. Skerrett (1996) and Mortimer and Constance (2000) also reported nesting on several islands. The constancy with which Red-tailed Tropicbirds flew over specific localities on the seaward slope of the northern dunes on Grand Ile and were seen to land among the Tournefortia bushes suggests that they may nest there.

Our observations on Ile du Sud-Ouest represent the first records of White Terns occupying possible breeding sites on Cosmoledo. Other terns were present in small numbers. None were noted as breeding although Black-naped Tern Sterna sumatrana, Crested Tern S. bergii and Brown Noddy Anous stolidus may do so. Black-naped Terns are widely but thinly distributed in the Amirantes, Providence, Farquhar and Aldabra groups of islands but, apart from Aldabra, records of breeding are scarce. Eggs were found on African Banks, Amirantes, in November 1976 (CJF pers. obs.), and on Aldabra they nest mainly in January-February, with some continuing until June, and one November record (Diamond and Prys-Jones 1986). Crested Terns nest on lagoon islets of Aldabra in December-January and also in June-July (Diamond and Prys-Jones 1986) and eggs were also recorded on African Banks, Amirantes, in June (CJF pers. obs.). The pale S. bergii thalassina of the western Indian Ocean is commonly seen in islands of the Seychelles, Amirantes, Providence, Farquhar and Aldabra groups, and yet the main breeding areas of this subspecies remain to be discovered. 


\section{Landbirds}

Turtle doves were first recorded on Cosmoledo by Rivers (1878) and later by Bergne (1901, in Benson 1970) and Dupont (1907), who listed the species as Turtur saturatus. Christiansen (1944) noted their presence on his visit but there were no further scientific visits to the atoll until Benson (1970), who concluded the species was "extinct except perhaps on South Island" (i.e. Ile du Sud-Ouest), which he was unable to visit. It was only in 1982 that turtle doves were reported confirmed to survive on this island (Mortimer 1984) and identified as "apparently Streptopelia picturata coppingeri as on Aldabra" (Mortimer 1984b). Despite the fact that most body measurements taken on the two Cosmoledo specimens were within the range of values we recorded on Aldabran turtle doves, the plumage characteristics and original ecology of the Cosmoledo turtle doves suggested that they may be a separate race. Additional individuals from Cosmoledo need to be described and measured before the morphological differentiation between the two populations can be more accurately assessed. First said to occur in 1982 in very small numbers restricted to a specific area of Ile du Sud-Ouest, the species was later described to be more widespread than had been originally thought (Mortimer and Constance 2000). A more detailed survey is needed to determine population size, but the size of the island ( $30 \mathrm{ha}$ ), combined with their relative scarcity, suggests a maximum of 50-100 individuals.

Despite the year-round abundance of seabird eggs and turtle hatchlings ( $\mathrm{J}$. A. Mortimer pers. comm.), numbers of Pied Crows on Cosmoledo appear very small (probably not more than 10-15 birds) when compared with Aldabra (c. 60-70 birds; Frith 1977, Betts 2000) or Europa (250-300 birds; Le Corre and Jouventin 1997a). Unlike these localities, Cosmoledo does not have a permanent settlement from where Pied Crows can benefit from refuse and artificial reserves of fresh water. However, crows were never reported to be common on Cosmoledo, even around the settlement and fishing camps where tens of people used to live (A. Constance and J. A. Mortimer pers. comm.). The extreme fragmentation of the islands of the atoll, imposing inter-island seacrossings on crows in search of food, probably prevents crows from using optimally the food resources available for them on the atoll. The small amount of land available on each island (as on the whole atoll when compared with Aldabra or Europa) is probably insufficient to support larger crow populations between periods of easy access to seabird eggs and turtle hatchlings on a particular island. Nevertheless, it was surprising that Pied Crows on Menai did not move to Grand Ile during the Sooty Tern breeding season to exploit the large potential food source in the colony.

\section{Conservation priorities and perspectives}

Cosmoledo Atoll is one of the most important and best preserved unspoilt ornithological sites, and certainly the finest unprotected site, in Seychelles. It hosts the largest booby colonies and one of the largest Sooty Tern colonies known in the Indian Ocean, including significant proportions of the world populations of Sterna fuscata nubilosa, Sula sula rubripes, and especially Sula dactylatra melanops. It probably also retains other breeding seabird populations of international 
importance (Red-tailed Tropicbird, Crested Tern and Black-naped Tern; Rocamora and Skerrett 2001) that could not be investigated during our short visit. In addition two, and possibly three, forms of endemic landbird breed and the lagoon is an important feeding ground for migratory birds, notably Crab Plover Dromas ardeola and Turnstone Arenaria interpres.

Paradoxically, Cosmoledo is the most poorly known of the main Important Bird Areas in Seychelles. Therefore, priority should be given to monitoring schemes to estimate population sizes and trends for all seabirds and landbirds present on the atoll throughout the year. Genetic studies to investigate the relationships between the seabird populations on Cosmoledo and other major colonies of the western Indian Ocean need to be conducted (samples were collected on this expedition), since this may have important conservation implications. It is, for example, likely that Red-footed Booby populations are isolated and genetically differentiated from each other, as suggested by variations in plumage polymorphism observed elsewhere in the region (Le Corre 1999). This emphasizes the importance of preserving each individual population. Morphological, genetic, ecological and vocal differentiation between the turtle dove populations of Cosmoledo and Aldabra need to be investigated to assess their affinities and taxonomic status. We also plan to conduct the same kind of comparative studies between the sunbird, white-eye and cisticola populations found on Cosmoledo and those elsewhere in the Aldabra group. Similar research aiming to investigate the specificity of other wildlife on Cosmoledo should also be encouraged, notably turtles, skinks, geckos, invertebrates, and plants, and marine communities.

Despite a long history of seabird exploitation between the mid-18oos and the mid-1990s (Mortimer and Constance 2000), the isolation of Cosmoledo and its rough terrain (particularly on Ile du Sud-Ouest) may have prevented the longterm overexploitation that could have led to the extinction of these colonies. The extreme fragmentation of the islands of the atoll probably also prevented introduced rats and cats from spreading to, or recolonizing, all the main islands of the atoll. As a result, Ile du Sud-Ouest is free of introduced predators, aiding the survival of the island's important seabird populations.

In addition to its ornithological importance, Cosmoledo also hosts important breeding populations of Green Turtle Chelonia mydas (the second largest in Seychelles) and Hawksbill Turtle Eretmochelys imbricata (Mortimer 1984a), and is the only site outside Madagascar where the endemic Malagasy lizard genus Zonosaurus occurs (Cheke 1984). In addition, Cosmoledo supports superb coral reefs and an outstanding marine life in general (Mortimer and Constance 2000; D. Rowat pers. comm.). Abandoned since 1992, the atoll urgently deserves protection and permanent wardening, as there is evidence of regular poaching threatening seabirds, turtles and other marine life (Mortimer and Constance 2000, D. Rowat pers. comm.). Because of its exceptional biological interest and international importance, we strongly suggest that Cosmoledo could should be granted protected status by the Seychelles Government. Previous studies (Piggott 1969, Gillham 1977, Feare 1984, Skerrett 1996, Mortimer and Constance 2000, Rocamora and Skerrett 2001) already supported the concept of declaring Cosmoledo atoll a nature reserve. The atoll fulfils all the necessary criteria for such designation, and this would facilitate application for international funding to establish and main- 
tain the necessary infrastructure and conduct multidisciplinary research and monitoring. Reserve status would complement the prestigious World Heritage Site of Aldabra in terms of species and habitat protection and encourage ecotourism to generate revenue. The establishment of a conservation and ecotourism project on Cosmoledo could be linked to development of facilities on Astove atoll (c. $45 \mathrm{~km}$ from Cosmoledo), which has an airstrip and a permanent settlement. Such a project would also benefit from a close collaboration with the Aldabra Research Station, managed by Seychelles Island Foundation. It is hoped that the formation, in 2001, of the Island Conservation Society, a Seychelles-based non-governmental organization, may facilitate the international recognition of the importance of the atoll, thereby encouraging its protection and thus the survival of its unique ecosystem.

Once Cosmoledo is granted some long-term protection, its restoration through eradication of introduced species, notably cats on Grand Ile, rats there and on Menai and, if still present, on Grand Ile and Polyte, and rabbits on Ile du SudOuest, should be the next priority. Such eradications have already been conducted successfully on islands of comparable size in Seychelles (Bird Island and Frégate, Merton 1999, Merton et al. 2001), and in other countries including New Zealand (review in Veitch and Bell 1990), Mauritius (Merton 1987) and the French Austral Territories (Chapuis et al. 2001). This would remove threats to bird populations, and make Cosmoledo a potential destination for transferred populations of rare endemic birds from Aldabra, such as the flightless Aldabra Rail Dryolimnas cuvieri aldabranus, which once existed on Cosmoledo but is now extinct (Rivers 1878, Dupont 1907, Mortimer 1984b), or the globally Near Threatened Aldabra Drongo Dicrurus aldabranus. Cosmoledo also once supported giant tortoises (Coe and Swingland 1984) and thus might provide a site on which some Aldabran tortoises could be established.

\section{Acknowledgements}

We are grateful to the Islands Development Company, and in particular to their Chairman Glenny Savy and Operations Manager Justin Moustache, for support to our expedition and provision of all the necessary transport facilities by boat and plane to Cosmoledo. We also wish to thank Captain Alvis and the crew of Lady Genevieve for their invaluable assistance and wonderful hospitality, as well as the IDC staff that attended to our requirements on Assumption and Farquhar. The Ministry of Environment and Transport of Seychelles has provided continued support for the studies of Sooty Terns undertaken by CJF, and for this expedition provided small equipment and food under the Sooty Tern monitoring programme. Jeanne Mortimer, Antonio (Mazarin) Constance, Rolph Payet and Glenny Savy provided very helpful comments and suggestions during informal discussions on an early draft of the manuscript.

\section{References}

Bayne, C. J., Cogan, B. H., Diamond, A. W., Frazier, J., Grubb, P., Hutson, A., Poore, M. E. D., Stoddard, D. R. and Taylor, J. D. (1970) Geography and ecology of Cosmoledo Atoll. Atoll Res. Bull. 136: 37-56. 
Benson, C. W. (1970) Land (including shore) birds of Cosmoledo. Atoll Res. Bull. 136: $67-82$.

Benson, C. W., Beamish, H. H., Jouanin, C., Salvan, J. and Watson, G. E. (1975) The birds of the Iles Glorieuses. Atoll Res. Bull. 176: 1-34.

Betts, M. (2000) Research Officer's annual report June 1999-June 2000. Seychelles Islands Foundation Internal Report.

Burger, A. E. and Betts, M. (2001) Monitoring populations of Red-footed Boobies, and frigatebirds Fregata spp, breeding on Aldabra Atoll, Indian Ocean. Bull. Brit. Orn. Club 121: $236-246$.

Carboneras, C. (1992) Sulidae. Pp. 312-325 in J. del Hoyo, A. Eliott and J. Sargatal, eds. Handbook of the birds of the world. Barcelona: Lynx Edicions.

Chapuis, J-L., Le Roux, V., Asseline, J., Lefevre, L. and Kerlau, F. (2001) Eradication of rabbits (Oryctolagus cuniculus) by poisoning on three islands of the subantarctic Kerguelen Archipelago. Wildl. Res. 28: 323-331.

Cheke, A. (1984) Lizards of the Seychelles. Pp. 331-36o in D. R. Stoddart, ed. Biogeography and ecology of the Seychelles Islands. The Hague: W. Junk.

Cheke, A. (2001) Booby Sula colonies in the Mascarene area (Indian Ocean): extinctions, myths and colour morphs. Bull. Brit. Orn. Club 121: 71-80.

Christianson, E. (1944) Outlying islands: inspections report for 1944 to the Govenor from Edward Christianson, Temporary Visiting Magistrate for the outlying islands, 4 December 1944. Seychelles Archives reference C/SS/74 Vol. II.

Coe, M. and Swingland, I. (1984) Giant tortoises of the Seychelles. Pp. 309-330 in D. R. Stoddart, ed. Biogeography and ecology of the Seychelles Islands. The Hague: W. Junk.

Diamond, A. W. (1971) The ecology of the seabirds of Aldabra. Phil. Trans. R. Soc. Lond. B 260: 561-571.

Diamond, A. W. (1974) The Red-footed Booby on Aldabra Atoll, Indian Ocean. Ardea 62: 196-218.

Diamond, A. W. (1975) Biology and behaviour of Frigatebirds Fregata spp. on Aldabra Atoll, Indian Ocean. Ibis 117: 302-323.

Diamond, A. W. (1994) Seabirds of the Seychelles, Indian Ocean. Pp. 258-267 in D. N. Nettleship, J. Burger and M. Gochfeld, eds. Seabirds on islands: threats, case studies and action plans. Cambridge, U.K.: BirdLife International (Conservation Series 1).

Diamond, A. W and Prys-Jones, R. P. (1986) The biology of terns nesting at Aldabra Atoll, Indian Ocean, with particular reference to breeding seasonality. J. Zool. Lond (A) 210: 527-549.

Dupont, R. (1907) Report on a visit of investigation to St Pierre, Astove, Cosmoledo, Assumption and the Aldabra Group. Seychelles Government, Mahé.

Feare, C. J. (1975) Scavenging and kleptoparasitism as feeding methods of Seychelles Cattle Egrets. Ibis 117: 388.

Feare, C. J. (1976a) The breeding of the Sooty Tern Sterna fuscata L. in the Seychelles, and the effect of experimental removal of its eggs. J. Zool. Lond. 179: 317-360.

Feare, C. J. (1976b) The exploitation of Sooty Tern eggs in the Seychelles. Biol. Conserv. 10: 169-182.

Feare, C. J. (1978a) The decline of Booby (Sulidae) populations in the western Indian Ocean. Biol. Conserv., 14: 295-305.

Feare, C. J. (1978b) Ringability and edibility. BTO News 93: 6.

Feare, C. J. (1984) Seabird status and conservation in the tropical Indian Ocean. Pp. 457471 in J. P. Croxall, P. G. H. Evans and R. W. Schreiber, eds. Status and conservation of the world's seabirds. Cambridge, U.K.: ICBP (Technical Publ. 2).

Frith, C. B. (1977) Life History notes on some Aldabran Land Birds. Atoll Res. Bull. 201: 1-17. 
Gillham, M. E. (1977) Observations on vegetation of Blue-faced Booby colonies on Cosmoledo Atoll, Western Indian Ocean. Atoll Res. Bull. 199: 1-11.

Korte, J. de (1991) Status and conservation of Indonesia's seabird colonies. Pp. 527-545 in: J. P. Croxall, ed. Seabird status and conservation: a supplement. Cambridge, U.K.: ICBP (Technical Publ. 11).

Le Corre, M. (1996) The breeding seabirds of Tromelin Island (western Indian Ocean): population sizes, trends and breeding phenology. Ostrich 67: 155-159.

Le Corre, M. (1999) Plumage polymorphism of Red-footed Boobies (Sula sula) in the western Indian Ocean: an indicator of biogeographic isolation. J. Zool. Lond. 249: 411-415.

Le Corre, M. (2001) Breeding seasons of seabirds at Europa Island (southern Mozambique Channel) in relation to seasonal changes in the marine environment. J. Zool. Lond. 254: 239-249.

Le Corre, M. and Jouventin, P. (1997a) Ecological significance and conservation priorities on Europa Island (western Indian Ocean), with special references to seabirds. Rev. Ecol. Terre Vie 52: 205-220.

Le Corre, M. and Jouventin, P. (1997b) Kleptoparasitism in tropical seabirds: vulnerability and avoidance responses of a host species, the Red-footed Booby. Condor 99: 162-168.

Lloyd, C., Tasker, M. L. and Partridge K. (1991) The status of seabirds in Britain and Ireland. The Nature Conservancy Council and The Seabird Group. London: T. and A. D. Poyser.

Merton, D. (1987) Eradication of rabbits from Round Island, Mauritius: a conservation success story. Dodo 24: 19-43.

Merton, D. (1999) The Seychelles: rats eradicated from Bird Island. Birding 31: 425.

Merton, D., Climo, G., Laboudallon, V. and Robert, S. (in press) Alien animal eradication and quarantine on islands in the Seychelles. In C. R. Veitch and M. N. Clout, eds. Turning the tide: the eradication of invasive species. Auckland: Invasive Species Specialist Group, IUCN.

Mortimer, J. A. (1984a) Marine turtles in the Republic of Seychelles: status and management. Gland, Switzerland: IUCN Conservation Library.

Mortimer, J. A. (1984b) Rediscovery of the Turtle Dove (Streptopelia picturata) on Cosmoledo Atoll in the Seychelles. Ibis 126: 81-82.

Mortimer, J. A. and Constance, A. (2000) Observations on the birds of Cosmoledo Atoll, Seychelles. Bull. Brit. Orn. Club 120: 46-57.

Nelson, J. B. (1978) The Sulidae: Gannets and Boobies. Oxford: Oxford University Press.

Newlands, W. A. (1976) A piece of the rock. Anim. Kingdom 79: 2-9.

Piggott, C. J. (1969) A report on a visit to the outer islands of Seychelles between October and November 1960. Tolworth, Surrey, U.K.: Land Resources Division, Directorate of Overseas Surveys.

Pitman, R. L. and Jehl, J. R. (1998) Geographic variation and reassessment of species limits in the Masked Boobies of the eastern Pacific Ocean. Wilson Bull. 110: 155-170.

Piton, B. and Magnier, Y. (1975) Remarques sur la circulation et les caractéristiques hydrologiques de la couche superficielle entre Madagascar et l'équateur. Cah. Off. Rech. Scient. Tech. Outre-Mer (Océanogr). 13: 117-132.

Polunin, N. V. C. (1979) Sula leucogaster and other species in the Iles Mitsios, Madagascar. Bull. Brit. Orn. Club 99: 110-111.

Reville, B. J. (1983) Numbers of nesting frigatebirds, Fregata minor and Fregata ariel on Aldabra Atoll Nature Reserve, Seychelles. Biol. Conserv. 27:59-76.

Ridley, M. W. and Percy, R (1958) The exploitation of sea birds in Seychelles. Col. Res. Stud. 25: 1-78.

Rivers, F. (1878). Report on the visit to Aldabra and other islands of the Cosmoledo group on board of the 'Flower of Jarrow'. Seychelles National Archives. 
Roberson, D. (1998) Sulids unMasked: which large boobies reach California. Field Notes 52: $276-287$.

Rocamora, G. and Skerrett, A. (2001) Seychelles. Pp. 751-768 in L. Fishpool and M. I. Evans, eds. IBAs in Africa and associated islands. Newbury and Cambridge, U.K.: Pisces Publications and BirdLife International.

Safford, R. (1993) Serpent Island in 1993. Proc. R. Soc. Arts Sci. Mauritius 5: 33-39.

Schreiber, E. A., Schreiber, R. W. and Schenk, G. A. (1996) Red-footed Booby (Sula sula). In A. Poole and F. Gill, eds. The birds of North America, 241. Washington, DC: Academy of Natural Sciences, Philadelphia and the American Ornithologists' Union.

Sinclair, I. and Langrand, O. (1998) Birds of the Indian Ocean islands. Cape Town: Struik.

Siorat, F. and Rocamora, G. (1995) Changes in numbers and distribution of the Northern Gannet (Morus bassanus) on Rouzic Island, (Reserve Naturelle des Sept-Iles, Bretagne), France 1939-1994. Col. Waterbirds 18: 172-178.

Skerrett, A. (1995) Birds of the Amirantes. Birdwatch 15: 10-20.

Skerrett, A. (1996) Ornithological observations south of the Amirantes. Birdwatch 18: 3-8.

Skerrett, A., Bullock, I. and Disley, R. (2001) Birds of Seychelles. London: A \& C Black.

Staub, F. and Gueho, J. (1968) The Cargados Carajos shoals of St Brandon: resources, avifauna and vegetation. Proc. R. Soc. Arts Sci. Mauritius 3: 7-46.

Swinnerton, K., Chapman, R. and Vadaparnaiken, B. (1996) A report on a visit to St Brandon by the Mauritian Wildlife Fund. St. Louis: Mauritian Wildlife Foundation.

Symens, P. (1999) Breeding seabirds of the Chagos Archipelago. Pp. 257-272 in C. R. C. Sheppard and M. R. D. Seaward, eds. Ecology of the Chagos Archipelago. Otley, U.K.: Westbury Publishing.

Veitch, C. R. and Bell, B. D. (1990) Eradication of introduced animals from the islands of New Zealand. Pp. 137-146 in D. R. Towns, C. H. Dougherty and I. A. E. Atkinson, eds. Ecological restoration of New Zealand islands. Wellington: Department of Conservation (Conservation Sciences Publication 2).

Vesey-Fitzgerald, D. (1941) Further contributions to the ornithology of the Seychelles Islands. Ibis (14) 5: 518-531.

Walsh, R. P. D. (1984) Climate of the Seychelles. Pp. 39-62 in D. R. Stoddart, ed. Biogeography and ecology of the Seychelles Islands. The Hague: W. Junk.

Wanless, S. (1987) A survey of the numbers and breeding distribution of the North Atlantic Gannet Sula bassana and an assessment of the changes which have occurred since Operation Seafarer 1969/1970. Petersborough, U.K.: Nature Conservancy Council (Report 4).

Williams, A. J. and Rowlands, B. W. (1980) Seabirds of the Cargados Carajos shoals, JulyAugust 1971. Cormorant 8: 43-48.

Williams, C. (1971) Geophysical measurements on Aldabra. Unpublished report to the Royal Society, London, Ald/8o (71): Appendix A.

\section{GÉRARD ROCAMORA}

Island Conservation Society, PO Box 775, Mahé, Seychelles and Centre de Recherches sur la Biologie des Populations d'Oiseaux. Museum National d'Histoire Naturelle. 55, rue de Buffon 75005 Paris. email: g_rocamora@hotmail.com

\section{CHRIS J FEARE}

Department of Pure and Applied Biology, University of Leeds, Leeds LS2 9JT and Wildwings Bird Management, 2 North View Cottages, Grayswood Common, Haslemere, Surrey GU27 2DN, UK. E-mail: feare-wildings@msn.com

\section{ADRIAN SKERRETT}

Island Conservation Society, PO Box 775, Mahé, Seychelles and Seychelles Bird Records Committee, PO Box 336, Seychelles. 
MAJELLA ATHANASE

Ministry of Environment and Transport, BP 445, Mahé, Seychelles.

EDWINA GREIG

clo WildWings Bird Management, 2 North View Cottages, Grayswood Common, Haslemere, Surrey GU27 2DN, U.K.

Received 10 October 2001; revision accepted 13 December 2002. 